\title{
Antioxidant and fatty acid profile of gabiroba seed (Campomanesisa Xanthocarpa Berg)
}

\author{
Potencial antioxidante e perfil dos ácidos graxos de sementes de gabiroba (Campomanesisa Xanthocarpa Berg)
}

\author{
Marli da Silva SANTOS ${ }^{1 \star}$, Obdulio Gomes MIGUEL ${ }^{2}$, Carmen Lúcia Oliveira PETKOWICZ³ \\ Lys Mary Bileski CÂNDIDO ${ }^{1,4}$
}

\begin{abstract}
This study aimed to evaluate the antioxidant potential and fatty acid profile of gabiroba (Campomanesia xanthocarpa Berg) seeds. In order to obtain the extract, the seeds were dried, crushed, and subjected to sequential extraction by maceration and percolation in a modified soxhlet extractor using solvent polarity gradient composed of hexane, chloroform, ethyl acetate, and alcohol, respectively. The extraction time was six hours. The ethanol extract showed the highest antioxidant potential, given by the $\mathrm{EC}_{50}$ value and the amount of total phenolic compounds. High amounts of unsaturated fatty acids were found in the oil studied, especially the oleic acid.

Keywords: technological use; native species; Brazilian flora.
\end{abstract}

\section{Resumo}

Este trabalho teve como objetivo avaliar o potencial antioxidante e perfil dos ácidos graxos em sementes de gabiroba (Campomanesia xanthocarpa Berg). Para a obtenção do extrato, as sementes foram desidratadas, trituradas e submetidas à extração sequencial por percolação e maceração, em extrator de Soxleht modificado, utilizando solventes com gradiente de polaridade, constituídos respectivamente por hexano, clorofórmio e acetato de etila e álcool. O tempo de cada extração foi de seis horas. O extrato etanólico apresentou o maior potencial antioxidante, dado pelo valor de $\mathrm{EC}_{50}$, bem como pela quantidade de compostos fenólicos totais. No óleo estudado, destacou-se maior porcentagem de ácidos graxos insaturados, sendo o principal componente o ácido oleico.

Palavras-chave: aproveitamento tecnológico; espécie nativa; flora brasileira.

\section{Introduction}

The Campomanesia xanthocarpa Berg, popularly known as gabirobeira, is a fruit of the Myrtaceae family, native species cultivated only in homegardens in Brazil, mainly in the South and Southeast regions (LORENZI et al., 2006). Rustic and resistant to adverse conditions, the species grows well in rough terrain and periodic flooding of low natural fertility, ideal for training forest. Its fruits are appreciated for their sensory characteristics and nutritional value serving food to large numbers of birds and small mammals, which are the main dispersers of their seeds (LORENZI et al., 2006). Until the 1980s, this fruit species was found in large quantities in many different habitats. However, nowadays, due to the adoption of new agricultural models, its presence is restricted to areas of permanent preservation, the risk of becoming extinct due to lack of commercial exploration (VIZZOTTO et al., 2008).

The seeds of the fruits of C. xanthocarpa are brown and have a cylindrical flat shape. They are located inside of the fruit protected by the endocarp. Based on physical analysis, it is observed that the seed is covered with mucilage. The seed tests were described by Berg (1978) as membranaceous and verrucosa-glanulosa. It is worth noting that this aspect has been used as an important taxonomic feature to define the genre in the family (SANTOS; FERREIRA; ÁGUILA, 2004).

It is known that some plant foods can potentially contain higher content of antioxidant compounds in the waste of skin, peel, and seeds than in the pulp, and the phytochemical profile may be distinguished in these parts of the plant (GUO et al., 2003).

The antioxidant activity of a substance is related to its ability to release hydrogen to react and eliminate the negative action of singlet oxygen (KAUR; KAPOOR, 2001). With regard to human health, phenolic compounds present in fruits and their derivatives, including anthocyanins, procyanidins, flavonols, and phenolic acids, together with the carotenoids and vitamin C, are responsible for the decreased risk of many diseases associated with oxidative stress (ABIDILLE et al., 2005).

In the fruits of Campomanesia xanthocarpa Berg, the possible action of antioxidants can be attributed mainly to the considerable levels of phenolic compounds, carotenoids, and

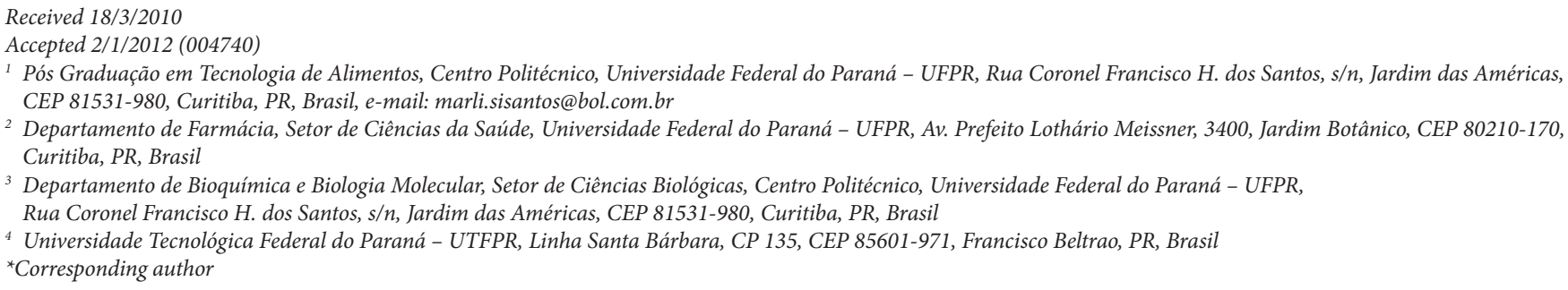


vitamin $\mathrm{C}$ present in this fruit. Other important components found mainly in seeds are the polyunsaturated fatty acids (BELDA; POURCHET-CAMPOS, 1991).

Studies on the presence of bioactive compounds and antioxidant potential of the seed of Campomanesia xanthocarpa, are scarce. Thus, the objective of this study was to determine the content of phenolic compounds, flavonoids, carotenoids, and the profile of fatty acids in the seeds of Campomanesia xanthocarpa Berg as well as to quantify the potential antioxidant activity using the stable free radical 2,2-diphenyl-1-picrylhydrazyl (DPPH) and 2,2 - azinobis 3-ethylbenzthiazoline-6-sulfonic acid (ABTS).

\section{Material and methods}

The fruits of Campomanesia xanthocarpa Berg were collected from native plants in the city of Itaiacoca, located near the city of Ponta Grossa in Parana State. Located approximately $975 \mathrm{~m}$ above sea level, showing how geographic coordinates $25^{\circ} 05^{\prime} 42^{\prime \prime}$ south latitude and $50^{\circ} 09^{\prime} 43^{\prime \prime}$ longitude west of Greenwich, the city has a humid subtropical mesothermic climate. According to the Instituto Brasileiro de Geografia e Estatistica (2008), the average rainfall is $1430.0 \mathrm{~mm}$ with minimum and maximum temperatures of 16.8 and $27{ }^{\circ} \mathrm{C}$, respectively. The samples were selected according to color uniformity, size, and damage absence.

To obtain the extracts, the seeds of Campomanesia xanthocarpa Berg were removed manually from the fresh fruit and slightly washed with distilled water to remove waste from pulp and soluble sugars. The seeds were dried in an oven with air circulation (model 400/D brand New Ethics) at $35^{\circ} \mathrm{C}$ for 12 hours, dried, and ground in a laboratory analytical mill (model A-11 mark IKA ${ }^{\circ}$ Works). The material was sieved through a 60 mesh screen, packed in airtight bottle, and then submitted to sequential extraction by maceration and percolation in a modified extractor Soxleht using solvent gradient polarity, respectively composed of hexane, chloroform, ethyl acetate, and alcohol. The extraction time of each sample was six hours.

In the analysis of fatty acid profile (obtained by hexane fraction), they were derivatized into methyl esters according to the standard procedure described in ISO 5509 method (INTERNATIONAL..., 2000). The fatty acid methyl esters were analyzed using gas chromatography according to ISO 1442 (INTERNATIONAL..., 1997). For the analysis of fatty acids, a gas chromatograph equipped with a flame-ionization detector and fitted with a DB-23 capillary column (GC-FID Shimadzu version 6.41) was used. The column temperature program was started at $110^{\circ} \mathrm{C}$ for 2 minutes, heated at $4{ }^{\circ} \mathrm{C} / \mathrm{min}$ to $240{ }^{\circ} \mathrm{C}$, and kept isothermally for 10 minutes. The injector and detector temperatures were 230 and $250{ }^{\circ} \mathrm{C}$, respectively. The fatty acids were identified by comparing the retention times of pure standards of fatty acid methyl esters with the separate components of the samples, and the fatty acid quantification was determined by area normalization method (\%). A standard mixture of 37 fatty acids methyl esters ranging from C4:0 to C24:1, with purity between 99.1 and $99.9 \%$, was used.
The total phenolics in the samples were measured by spectrophotometry in the visible region using the Folin Ciocalteu method (SINGLETON; ROSSI, 1965). The results were expressed as milligrams of gallic acid equivalents (GAE) per gram of extract $\left(\mathrm{mg} \cdot \mathrm{g}^{-1}\right)$.

The level of antioxidant activity was evaluated in vitro with the spectrophotometric method using the stable free radical 2,2-diphenyl-1-picrylhydrazyl (DPPH), proposed by BrandWilliams, Cuvelier, and Berset (1995), in triplicate. A solution of DPPH in ethanol was prepared. The extracts were diluted in ethanol in the following concentrations: 10, 25, 50, 100,200, and $250 \mu \mathrm{g} . \mathrm{mL}^{-1}$. Ethanol was used as a blank. The negative control was prepared with the solution of DPPH and ethanol. A solution of 6-Hydroxy - 2.5.7.8 - tetra methyl chroman-2-carboxylic acid (trolox), which has high antioxidant capacity was used as a positive control. The solution of DPPH has an intense red color, and the antioxidant action of an extract can be confirmed by the progressive discoloration of the solution, which becomes yellowish. The absorbance was read after 60 minutes at $517 \mathrm{~nm}$ in an UV-1601 Shimadzu spectrophotometer.

The absorbance values were converted into percentage of antioxidant activity (AA\%) using the following Equation 1:

$\%$ AA $=\frac{([\text { Abs control }-(\text { Abs sample }- \text { Abs blank })] \times 100)}{\text { Abs control }}$

where $\% \mathrm{AA}=$ percentage of antioxidant activity. Abs sample $=$ absorbance of sample. Abs blank $=$ absorbance of blank . Abs control $=$ absorbance of control.

Abs control is the initial absorbance of ethanolic solution of DPPH and Abs sample is the absorbance of the reaction mixture (DPPH + sample). The method described by Larrauri, Ruperez and Saura-Calixto (1997) was used with some modifications. A solution of 2,2-azinobis 3-ethylbenzthiazoline-6-sulfonic acid (ABTS) $7.0 \mathrm{mM}$ in ethanol was prepared, and it was mixed with a solution of potassium persulphate $2.45 \mathrm{mM}$ at the ratio of $1: 1$ and left resting for 12 hours at room temperature $\left(28 \pm 2^{\circ} \mathrm{C}\right)$ in the absence of light. After that time, the reagent was diluted with ethanol to obtain an absorbance value of $0.7 \pm 0.05 \mathrm{~nm}$ to $734 \mathrm{~nm}$. The sample reading was taken after seven minutes of reaction. The samples were diluted in ethanol. All readings were made in triplicate and the results were expressed as mMol of trolox per gram of sample.

The extraction and quantification were performed according to the method of Rodriguez-Amaya (1999). The extracts were dissolved in acetone and transferred to a separatory funnel containing petroleum ether, and several washes with distilled water were performed until complete removal of acetone. Next, the extract was transferred to a volumetric flask, and the analysis was conducted using petroleum ether.

The solution was analyzed in a spectrophotometer with scan rates of $350-550 \mathrm{~nm}$. In the quantification of carotenoids, the parameters based on the major carotenoid (beta carotene) in the fruit were evaluated according to Davies (1976), who applies the Beer's law and presents a table of absorptivity. The tests were performed in triplicate and evaluated by analysis of variance (ANOVA) and differentiation of means by the Tukey test with a level of significance of 5\% using Microsoft Office Excel 2003. 


\section{Results and discussion}

The moisture content of the seeds of Campomanesia xanthocarpa Berg was $7.67 \%$ on a dry seed weight basis and oil content of $12.67 \%$, which was obtained by extraction with hexane. The ethanol extract showed the highest yield, $27.67 \%$, followed by the fraction obtained from chloroform, $14.88 \%$, and the extract with the lowest yield was that obtained from ethyl acetate $9.57 \%$ The yield of the extracts is directly related to the type of solvent used, and this percentage can also vary depending on the technique used and the matrix used as raw material, which may be based on different chemical mechanisms (FERNANDES, 2002).

Several methods and solvent systems are used for the extraction of polyphenols from plant products, especially fruits and their products, in order to determine the antioxidant capacity

Table 1. Content of phenolic compounds and carotenoids in extracts of seeds of C. xanthocarpa Berg.

\begin{tabular}{ccc}
\hline Extracts & $\begin{array}{c}\text { Total phenolic compounds } \\
\left(\mathrm{mg} \mathrm{GAE} .100 \mathrm{~g}^{-1}\right)^{1}\end{array}$ & $\begin{array}{c}\text { Total carotenoids } \\
\left(\mu \mathrm{g} . \mathrm{g}^{-1} \text { beta carotene }\right)\end{array}$ \\
\hline Ethanolic & $176.56 \pm 0.05$ & $25.21 \pm 1.56$ \\
Hexane & $43.32 \pm 0.45$ & $79.40 \pm 0.78$ \\
Chloroform & $64.51 \pm 0.32$ & $23.11 \pm 2.12$ \\
Ethyl acetate & $86.37 \pm 0.22$ & $48.42 \pm 1.09$ \\
\hline
\end{tabular}

${ }^{1}$ GAE. $100 \mathrm{~g} \mathrm{~g}^{-1} \mathrm{mg}$ - Equivalent in Gallic Acid.
(PRIOR; WU; SCHAICH, 2005). Several studies have reported that the type of solvent and its polarity can affect the transfer of electrons and hydrogen atoms, which is the primary measure of antioxidant capacity. The presence of antioxidant compound in the solutions tested can also affect the results (PÉREZJIMÉNEZ; SAURA-CALIXTO, 2006). The content of total phenolic compounds in seed extracts of C. xanthocarpa Berg ranged from $176.56 \pm 0.05$ to $86.37 \pm 0.22 \mathrm{mg}$ GAE. $100 \mathrm{~g}^{-1}$, and the fraction obtained with ethanol showed the best result, as shown in Table 1 . The antioxidant activity of the phenolic compounds is attributed to the reducing power of the phenolic group, which reduces free radicals and produces the phenoxyl radical, which, in turn, is stabilized by resonance. This ability is influenced by the number of hydroxyl groups present, for their positions, and the positions of glycosylation sites (WILMSEN; SPADA; SALVADOR, 2005).

The highest content of carotenoids was obtained in the hexane fraction and the lowest in the fraction obtained from ethyl acetate due to affinity of these components with solvents of low polarity. The antioxidant activity was assessed using the DPPH radical-scavenging method, in which the antioxidant compound transfers electrons to DPPH and lose its characteristic purple coloring. This test was chosen because it is simple and sensitive. Through regression analysis between the percentage of oxidation inhibition and the sample concentration, different equations and angular coefficients for the extracts evaluated were obtained. The antioxidant activity of the compounds,
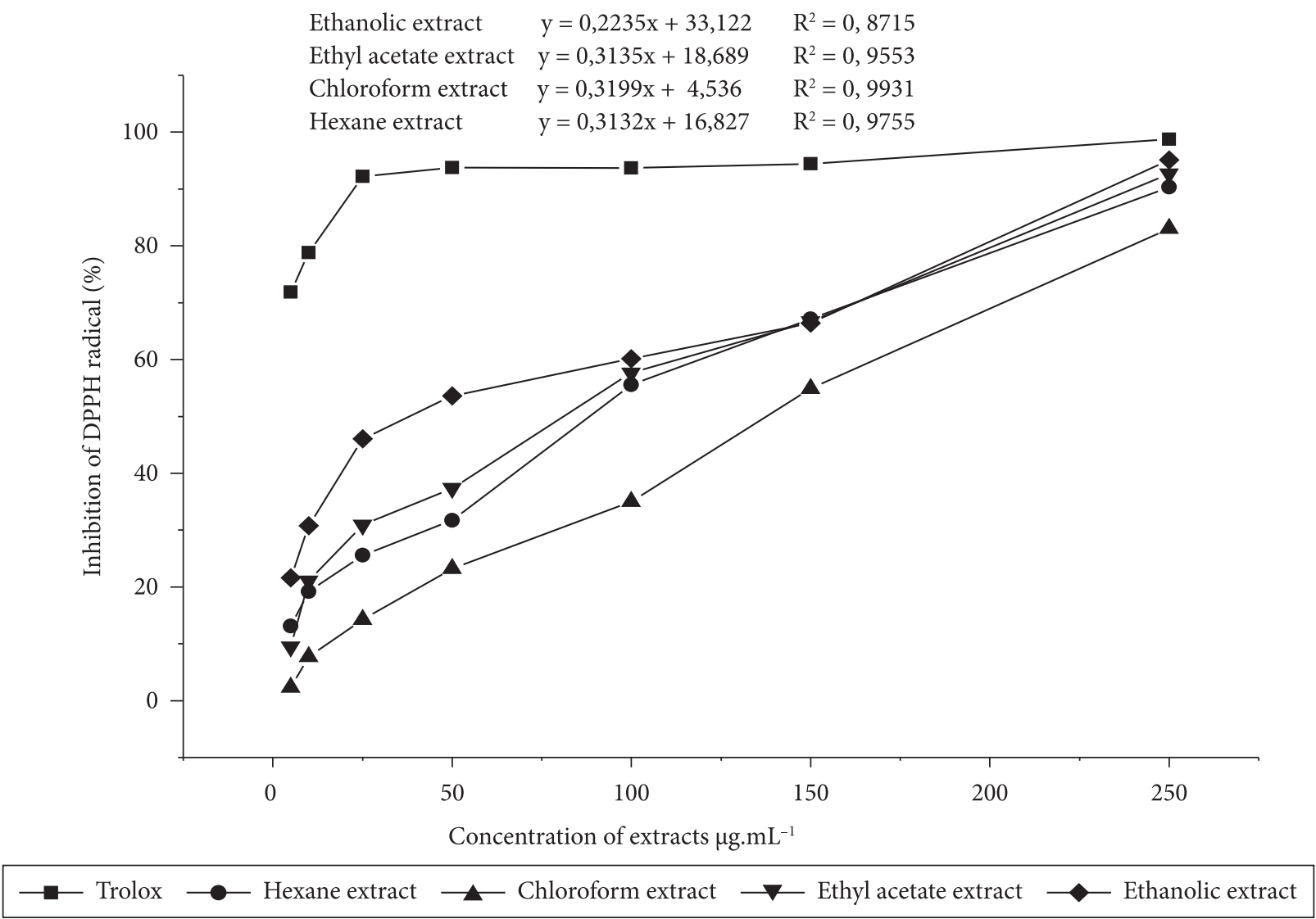

Figure 1. Percent inhibition of DPPH radical oxidation as a function of the concentrations of seed extracts of C. xanthocarpa Berg. 
Table 2. Potential antioxidant Trolox equivalent expressed in $\mathrm{mMol.g}{ }^{-1}$.

\begin{tabular}{|c|c|c|c|c|}
\hline Concentration $\left(\mu \mathrm{g} \cdot \mathrm{mL}^{-1}\right)$ & Ethanol extract & Hexane extract & Chloroform extract & Ethyl acetate extract \\
\hline 5 & $3.10 \pm 0.82$ & $1.33 \pm 0.12$ & $1.41 \pm 0.25$ & $1.32 \pm 0,03$ \\
\hline 10 & $9.15 \pm 0.46$ & $2.69 \pm 0.21$ & $2.07 \pm 4.28$ & $2.75 \pm 0.05$ \\
\hline 25 & $10.55 \pm 0.19$ & $4.27 \pm 1.10$ & $3.91 \pm 0.06$ & $4.75 \pm 0.1$ \\
\hline 100 & $25.38 \pm 1.03$ & $7.03 \pm 2.09$ & $4.62 \pm 1.79$ & $10.16 \pm 3.21$ \\
\hline 150 & $27.28 \pm 1.39$ & $8.58 \pm 2.27$ & $6.86 \pm 1.59$ & $16.40 \pm 0.05$ \\
\hline
\end{tabular}

Table 3. Fatty acids present in the lipid fraction of seeds Campomanesia xanthocarpa Berg.

\begin{tabular}{lr}
\hline Fatty acids & \multicolumn{1}{c}{$(\%)$} \\
\hline C16:0- Palmitic & $13.91 \pm 0.01$ \\
C17:0-Heptadecanoic & $0.08 \pm 0.02$ \\
C18:0- Stearic & $2.67 \pm 0.04$ \\
C16:1-Palmitoleic & $1.16 \pm 0.85$ \\
C17:1- Heptadecanoic & $0.11 \pm 0.05$ \\
C18:1 $n$ 9 c- Oleic & $60.84 \pm 0.00$ \\
C18:2 $n$ 6 c- Linoleic & $14.15 \pm 0.01$ \\
C18:3n 3 -Linolenic & $0.53 \pm 0.04$ \\
C20:0- Araquidico & $0.51 \pm 0.14$ \\
C20:4 $n$ 6-Arachdonico & $0.63 \pm 0.06$ \\
C20:1- Eicoseinoic & $0.32 \pm 0.01$ \\
C22:0 - Behen & $0.33 \pm 0.06$ \\
C24:0 - Lingnoceric & $0.13 \pm 0.04$ \\
Total saturad & 17.62 \\
Total monounsaturated & 62.42 \\
Total polyunsaturated & 15.31 \\
Total trans isomers total & $<0.01$ \\
Unidentified & 4.66 \\
\hline
\end{tabular}

Note: mean \pm standard deviation.

given by the $\mathrm{EC}_{50}$, is calculated by the reduction of $50 \%$ of the initial concentration of DPPH. It is noteworthy that the lower the $\mathrm{EC}_{50}$, the higher the antioxidant activity of the compound analyzed. The values of $\mathrm{EC}_{50}$, obtained by regression analysis for the extracts, showed significant coefficient of determination as shown in Figure 1.

The lowest $\mathrm{EC}_{50}$ values found for the extracts from the seeds of C.xanthocarpa Berg were 75.52 and $99.87 \mu \mathrm{g} . \mathrm{mL}^{-1}$ for the fractions with ethanol and ethyl acetate, respectively. The highest values of $\mathrm{EC}_{50}$ found were 105.91 and $142.11 \mu \mathrm{g} \cdot \mathrm{mL}^{-1}$ for the fractions with hexane and chloroform, respectively. Santos, Ferreira and Águila (2004) found high antioxidant activity for the extract of papaya seeds $98.92 \%$. The C. xanthocarpa Berg seed extract presented the highest inhibitory ability $(95.12 \%)$ was obtained with ethanol. The antioxidant activity data obtained using the DPPH radical-scavenging method indicated that the secondary compounds with antioxidant activity were found preferably in the most polar extracts possibly due to the fact that were it was extracted with more flavonoids and polyphenolic constituents. The extract that showed lesser inhibitory ability was obtained with chloroform.
The relationship between the concentration of total phenols and the ability to sequester free radicals of the extracts was significant since the extract with the highest concentration of total phenolics was also that with the greatest potential for antioxidant activity. There was no significant difference ( $p>0.05$ ) between the ability of the extracts to inhibit the action of DPPH radical. The antioxidant activity may depend on several factors including the colloidal properties of substrates, conditions and oxidation steps, formation and stability of the radicals, as well as the possible location of antioxidants and stability in different stages of processing. According to PérezJiménez and Saura-Calixto (2006), the differences observed in antioxidant activity when using different extracting solvents may be higher if the analyzed sample is a complex matrix of different components, which may determine many different interactions among themselves and with the solvents. These authors found significant differences in antioxidant activity using the ABTS method influenced by the polarity of the solvent; higher values were found for more polar solvents. The data obtained by the ABTS method for determining the antioxidant profile of extracts are presented in Table 2. The results were obtained from a calibration curve $\left(y=0,003 x+0,7958\right.$ with $\left.R^{2}=0.9947\right)$ and expressed in $\mathrm{mMol} . \mathrm{g}^{-1}$ trolox.

The results demonstrate statistically significant difference ( $p=0.004$ ) between the antioxidant profile of extracts from the seeds of $C$. xanthocarpa Berg by ABTS method, and this difference may be due to the complexity of the sample in which the sequential extraction facilitates obtaing different substances with antioxidant capacity.

Table 3 presents the profile of fatty acids identified by gas chromatography and the lipid fraction present in the seeds of Campomanesia xanthocarpa Berg.

The fatty acid composition of the seeds of C. xanthocarpa Berg is especially characterized by oleic acid (60.84\%), palmitic (13.91\%), and linoleic (14.15\%). The total amount of unsaturated fatty acids was $77.73 \%$, of which $62.42 \%$ monounsaturated fatty acids and $15.31 \%$ polyunsaturated fatty acids. Oleic acid was the main constituent of the oil extracted. Oleic acid is important to the human body. It plays a key role in the synthesis of hormones and is also present in high concentration in grape seed, canola, sesame, sunflower, soybean, palm, and olive oil and marine animals, such as shark and codfish.

This type of raw material has wide application in the pharmaceutical industry. It is used in cosmetic emulsions and 
creams for its emollient properties and to replenish the oils in dried scaling skin. It is used for tanning purposes due to its ability to protect and regenerate skin damage and burns caused by sunlight (SILVA, 2005).

\section{Conclusions}

The oil obtained from the seeds of Campomanesia xanthocarpa Berg showed significant levels of bioactive compounds, and the results of fatty acid contents indicated a high degree of unsaturation. A product rich in oleic acid and linoleic acid, which means high antioxidant activity and emollient properties, was obtained through the solvent extraction process. Such product may have a wide range of application in the cosmetics industry: moisturizers, shampoos, bath oils, and soaps. It could also be used in pharmaceuticals, paints, food, and others.

\section{References}

ABIDILLE, M. D. H. et al. Antioxidant activity of the extracts from Dillenia indica fruits. Food Chemical, v. 90, n. 4, p. 891-896, 2005. http://dx.doi.org/10.1016/j.foodchem.2004.09.002

BELDA, M. C. R.; POURCHET-CAMPOS, M. A. Essential fatty acids in nutrition: an updated view. Science and Food Technology, v. 11, n. 01, p. 5-35, 1991.

BERG, O. C. Myrtaceae. In: MARTIUS, K. F. P. von (Org.). Flora Brasiliensis, v. 14, p. 1-656. 1978.

BRAND-WILLIAMS, W.; CUVELIER, M. E.; BERSET, C. Use of a free radical method to evaluate antioxidant activity. Lebensmittel - Wissenschaft und Technologie, v. 28, n. 01, p. 25-30, 1995.

DAVIES, B. H. Carotenoids. In: GOODWIN, T. W. (Ed.). Chemistry and biochemistry of plant pigments. London: Academic Press, 1976. v. 2, p. 38-165.

FERNANDES, J. B. Extraction of seed oils of citrus and its activities on the leaf-cutting ant Atta sexdens and its symbiotic fungus. Chemistry, v. 25, n. 06B, p. 1091-1095, 2002.

GUO, C. et al. Antioxidant activities of peel, pulp and seed fractions of common fruits as determined by FRAP assay. Nutrition Research, v. 23, p. 1719-1726, 2003. http://dx.doi.org/10.1016/j. nutres.2003.08.005

INSTITUTO BRASILEIRO DE GEOGRAFIA E ESTATISTICA - IBGE. SIDRA - Pesquisa Nacional de Saneamento Básico. Disponível em: <http://www.sidra.ibge.gov.br/bda/tabela/protabl.asp $>$. Acesso em: 25 jan. 2008.

I N T E R N A T I O N A L O R G A N I Z A T I O N F O R STANDARDIZATION - ISO. Method 5509: Animal and vegetable fats and oils preparation of methyle esters of fatty acids. ISO, 2000.

I N T E R N A T I O N A L O R G A N I Z A T I O N F O R STANDARDIZATION - ISO. Method 1442: Meat and meat products. Determination of moisture contente. ISO, 1997.

KAUR, C.; KAPOOR, H. C. Antioxidants in fruits and vegetables - the millennium's health. International Journal of Food Science and Technology, v. 36, n. 7, p. 703-725, 2001. http://dx.doi.org/10.1046/ j.1365-2621.2001.00513.x

LARRAURI, J. A.; RUPEREZ, P.; SAURA-CALIXTO, F. Effect of drying temperature on the stabilitity of polyphenols and antioxidant activity of red grape pomace peels. Journal of Agricultural and Food, v. 45, p.1390-1393, 1997. http://dx.doi.org/10.1021/jf960282f

LORENZI, H. et al. Brazilian fruits and exotic crops (for fresh consumption). Nova Odessa: Editora Plantanum, 2006. v.1, 674p.

PÉREZ-JIMÉNEZ, J.; SAURA-CALIXTO, F. Effect of solvent and certain food constituents on different antioxidant capacity assays. Food Research International, v. 39, n. 7, p. 791-800, 2006. http:// dx.doi.org/10.1016/j.foodres.2006.02.003

PRIOR, R. L.; WU, X.; SCHAICH, K. Standardized methods for the determination of antioxidant capacity and phenolics in food and dietary supplements. Journal of the Agricultural and Food Chemistry, v. 53, n. 10, p. 4290-4302, 2005. PMid:15884874. http:// dx.doi.org/10.1021/jf0502698

RODRIGUEZ-AMAYA, D. B. A guide to carotenoid analysis in foods. Washington: ILSI Press, 1999. 64 p.

SANTOS, C. R.; FERREIRA, A. G.; ÁGUILA, M. E. A. Characteristics of fruit and seed germination of six species of native Myrtaceae of Rio Grande do Sul. Revista Forest Science, v. 14, n. 2, p. 13-20, 2004.

SILVA, R. Study of optical properties of absorption and photoluminescence of oleic acid-doped beta-carotene. 2005. 78 f. Dissertação (Mestrado em Física)-Universidade Federal do Pará, Belém, 2005.

SINGLETON, V. L.; ROSSI, J. A. Colorimetry of total phenolics with phosphomolybdic-phosphotungstic acid reagents. American Journal of Enology and Viticulture, v. 16, p. 144-158.1965.

VIZZOTTO, M. et al. Quantification of phenolic compounds, anthocyanins, carotenoids, and determination of antioxidant activity in bracts of hibiscus (Hibiscus sabdariffa L.). In: CONGRESSO BRASILEIRO DE CIÊNCIA E TECNOLOGIA DE ALimenTOS, 21., 2008, Belo Horizonte. Anais... Belo Horizonte, 2008.

WILMSEN, P. K. SPADA, D. S.; SALVADOR, M. Antioxidant activity of the flavonoid Hesperidin in chemical and biological systems. Journal of Agricultural and Food Chemistry, v. 53, n. 12, p.4754-4761, 2005. PMid:15941311. http://dx.doi.org/10.1021/ jf0502000 